clear, colourless solutions which can be used for the measurement of optical rotation.

The phospholipin-free material was found to be fully antigenic in rabbits and induced the formation of specific-agglutinins and precipitins and 'Shiga' heterophile immune-body. It would appear, therefore, that the phospholipin component of the complex is not essential for the manifestation of antigenic properties or for the capacity of the complex to induce the formation of hæmolytic heterophile immune-body ${ }^{3}$.

This work is being continued with antigenic material that has been isolated from selected strains of $B$. typhosum which are known to contain the characteristic ' $O$ ', ' $V i$ ', ' $O+V i$ ' or 'Rough' antigens respectively.

Biochemical Department, Lister Institute of

Preventive Medicine, London, S.W.1. May 20.

${ }^{2}$ Boivin and Mesrobeanu, C.R., Soc. Biol., 112, 76 (1933) ; Mesrobeanu and Calalb, C.R. Soc. Biol. 122,496 (1936); Rristrick
and Topley, Brit. J. Exp. Path., 15, 113 (1934).

2 Morgan, Chem. and Industry, 57, 976 (1938).

${ }^{3}$ Morgan, Biochem. J., 31, 2003 (1937).

- Henderson, Brit. J. Exp. Path., 20, 11 (1939).

\section{Binocular Stereoscopic Vision}

Wirth reference to a letter of mine in NATURE of December 10, 1938, Father William O'Leary, of Riverview College Observatory, Riverview, N.S.W., wrote to me shortly before his death, and, after mentioning that he also for many years past had been able to view stereoscopic pictures without a stereoscope, says: "The stereoscopic effect is also quite easily obtained by reversing the position of the pictures, putting the right to left and the left to right. If now, instead of focusing the eyes for parallel distant vision, we cross the eyes, the left eye then sees the right-hand picture and the right the left-hand picture. For some people this is rather painful, but I find no difficulty. The effect is a combination image, seemingly just half-way distant between the eyes and the two pictures, in fact, a miniature picture, but beautifully sharp in detail."

It took some practice before I was able to observe the phenomenon thus described by Father O'Leary, but I did succeed, and it has now become fairly easy. I hold the reversed stereo pictures in my left hand at about 18 inches distance and gaze at the tip of my right thumb placed in line with or a little below the lower edge of the pictures and about 6 inches from the eyes. This causes a squint so that the right eye sees mainly the left picture, and the left eye the right picture, as described by Father O'Leary. By some practice two of the four rather vague images coalesce, and the thumb can then be removed. The stereoscopic image is fairly easily held, and will survive short periods of closure of the eyes as in winking, but not much longer ones.

The most remarkable feature of the phenomenon seems to $m e$ to be the size of the image. It appears, as Father O'Leary says, about half the normal size, and, it is thus quite easy, holding the pictures at about the distance of ordinary vision, to see a normal size stereoscopic image by the commoner method, or an apparently half-size one by the cross-eye method. In the latter case, when the stereoscopic equilibrium is upset, the pictures appear to revert to their normal size.
Another curious point deserves notice. While observing this stereoscopic effect, I closed one eye, expecting to see the resulting two images resume their apparent normal size. There was, however, little or no noticeable change; it seemed only to come about on reopening the closed eye. This appears to involve the rather remarkable conclusion that an object appears to be smaller when seen by one eye than when seen by both. Perhaps the binocular image is really a little bigger than the monocular image, but this does not seem sufficient to account for the marked difference in apparent size between the two kinds of stereoscopic image. Since the phenomenon is entirely subjective it can scarcely be appreciated by those who have not observed it. In only one point does my observation differ from Father O'Leary's description. To me, by the cross-eye method (as by the other), the stereoscopic image is of the same size as the two adjacent images, and is in the same plane with them, not in a plane half way between them and the eyes; but here I may be misinterpreting Father O'Leary's meaning.

It follows from what has been said, that stereoscopic pictures can be observed by the cross-eye method when considerably separated, if viewed from a sufficient distance. At eight feet distance the pictures may be separated by two feet or rather more, and in this case the other two images fall each on the blind-spot of its receiving eye, so that the only image observed is the stereoscopic one. Father O'Leary suggests that stereoscopic pictures, suitably placed, and projected on a screen, could be observed by the cross-eye method, and this seems to be quite a practicable proposition, its only drawback being, perhaps, the reduced size of the image. I hope that someone will be able to explain this difference in apparent size.

Organic Chemistry Department,

T. S. Patterson.

University of Glasgow. May 9.

Spectroscopic Power of a Human Eye due to Injury

Wiтh reference to Prof. Kerr Grant's recent com. munication on this subject ${ }^{1}$, I wish to refer to communications on this subject by myself and others ${ }^{2,3}$ under the title "Conjunctival Halos".

In cases of this sort, it is important to note whether the centre of the ring-system is light or dark. Thus in that described by Mr. Barton ${ }^{3}$ it was light and "A very approximate measurement of the first red ring gave its angular diameter as $7^{\circ}$, in fair agreement with the value [radius $4^{\circ} 4^{\prime}$ ] quoted in Mr. Melmore's letter". No agreement is possible, for in my case the centre of the system was dark. But taking the 'grating interval' equal to $0.0125 \mathrm{~mm}$. and $\lambda$ equal to $0.0007 \mathrm{~mm}$., and applying the equation appropriate to a bright centred system the angular diameter works out at $6^{\circ} 24^{\prime}$. This is in good agreement with the result of Mr. Barton's own measure. ment.

The value given by Prof. Grant for the angular radius of the first order red ring accords well with the value found by me for a dark-centred system.

$$
\begin{gathered}
\text { Acomb, York. } \\
\text { May } 1 .
\end{gathered}
$$

${ }^{1}$ Grant, K., NATURe, 143, 726 (1939).

2 Melmore, S., NATURE, 127, 15 (1931).

3 Barton, A. W.; Parsons, J. H., NAtURe, 127, 308 (1931). 